emerged and died, being discovered April 2, 1893. On April 3, 1893, all of the remaining galls were opened Every one contained an insect, either as adult, pupa, or in one case (that of the smallest gall only $3 \mathrm{~mm}$. in diameter) a small shrivelled larva. The occupants were as follows : Dead adults (including the two that had emerged), I 2 ; live adults, 6 ; pupae, I8; larva, I. The pupa usually bears the cast larval skin attached dorsally to the anal extremity.
The gall-fly is 4 to $4 \frac{1}{2} \mathrm{~mm}$. long. The whole insect is black, except the abdomen and legs which are orange-red. Wings subhyaline, shaded with fuscous. It is a notable fact that no sign of a parasite was discovered in all of these galls.

I am indebted to Mr. Wm. H. Ashmead for identifying the Rhodites. It is a very pretty species. The abdomen changes to a dark but very highly polished brown in dried specimens.

\title{
THE BOMBYLID GENUS ACREOTRICHUS IN AMERICA.
}

BY D. W. COQUilletT, WASHINGTON, D. C.

For several years past the writer has enjoyed the privilege of examining many interesting forms of Diptera taken by Prof. O. B. Johnson in various parts of the state of Washington, and several of these have been made known from time to time in our various entomological journals. Among a recent sending is a single specimen belonging to the Bombylid genus Acreotrichus of Macquart, heretofore known only from Australia. It is closely related to the genus Phthiria, differing in the structure of the antennae and in the densely hairy face. The species is as follows :

Acreotrichus americanus n. $\mathrm{sp} . \delta$. Black, including the palpi and knob of halters, only the stem of the latter is yellow. Eyes contiguous, frontal triangle and face gray pollinose, face and underside of head densely long black pilose. Antennae slightly longer than the head, first joint twice as long but not wider than the second, the latter as broad as long, both densely long black pilose; third joint slightly over twice as long as the first, at its base narrower than the second joint, continuing slender nearly to the middle, then rather suddenly expanding to nearly twice its former width, the greatest expansion being on its upper side, then tapering quite suddenly to the tip which is blunt; a short, blunt-pointed style on the upper side of this joint a short distance before the apex; on the upper edge of the expanded portion of this joint are five black bristly hairs, each nearly half as long as the joint itself. Proboscis as long as the head and thorax taken together, the labella very narrow; palpi filiform, twofifths as long as the proboscis. Thorax velvety, the front corners, sides and pleura gray pollinose, its pile black; scutellum velvety, densely black pilose. Abdomen velvety, its pile light yellowish. Wings hyaline, stigma yellow, second submarginal cell not appendiculate, small crossvein scarcely beyond the middle of the discal cell. Length $7 \mathrm{~mm}$. Washington. A single specimen captured April 4, I894 (O. B. Johnson). 

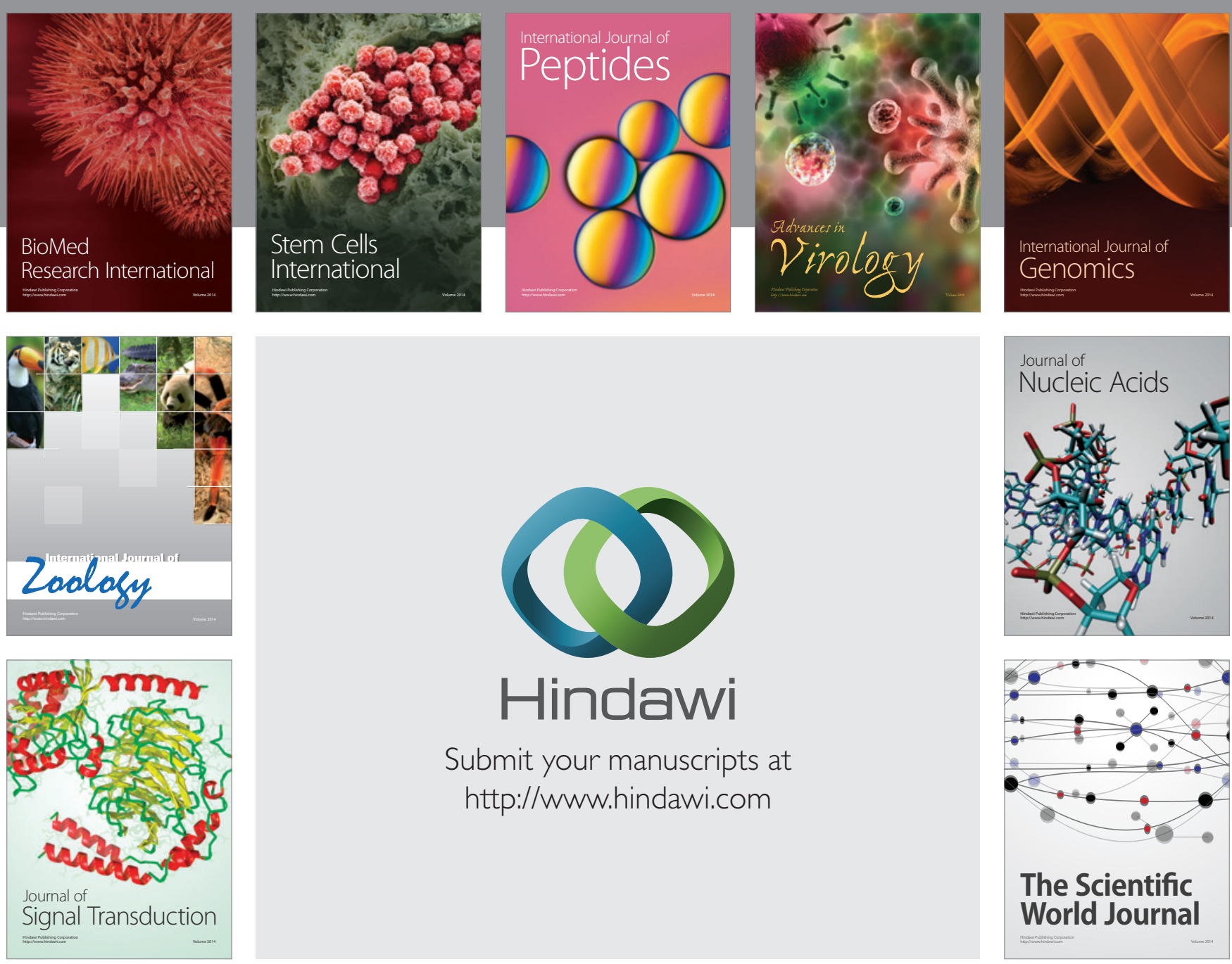

Submit your manuscripts at

http://www.hindawi.com
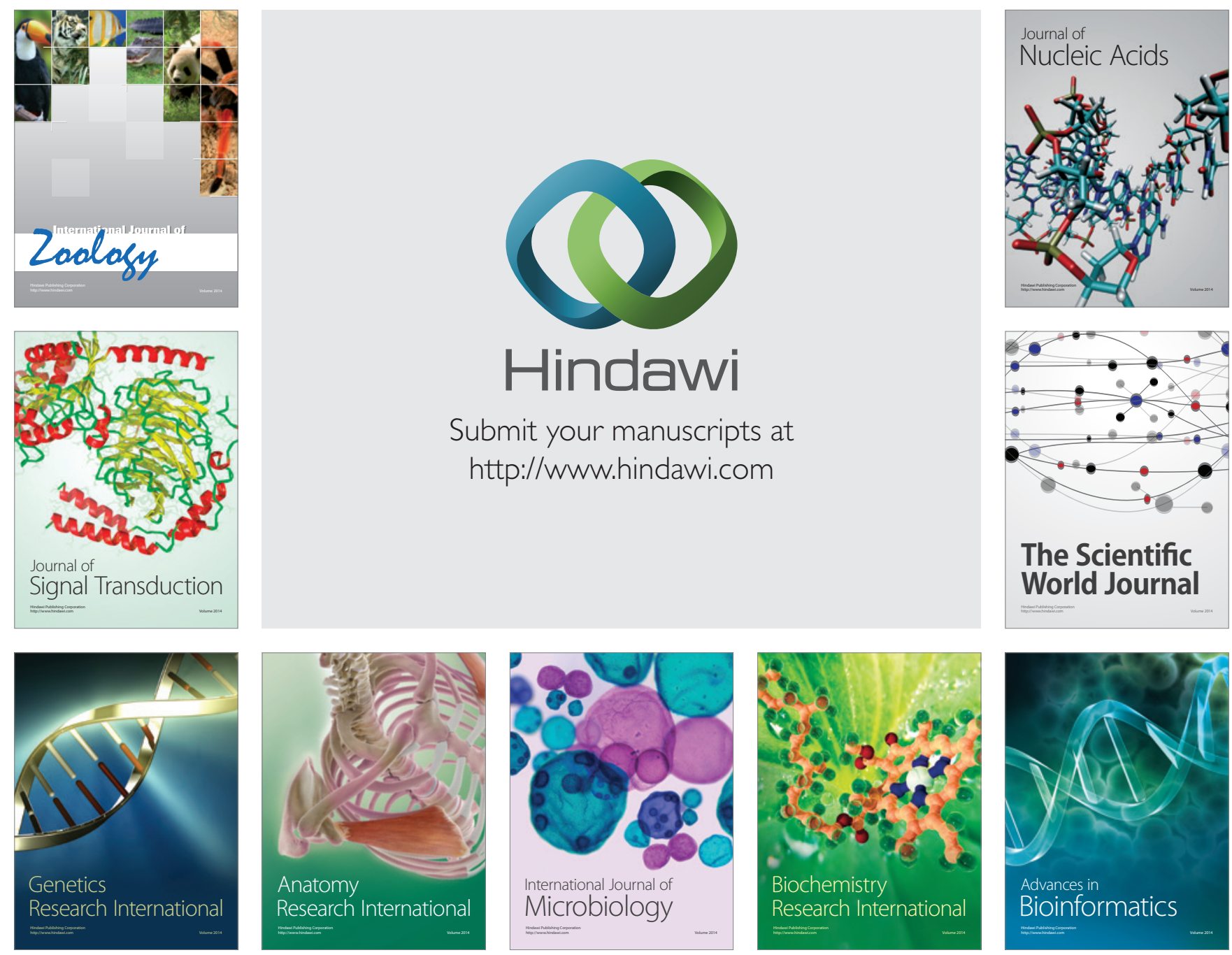

The Scientific World Journal
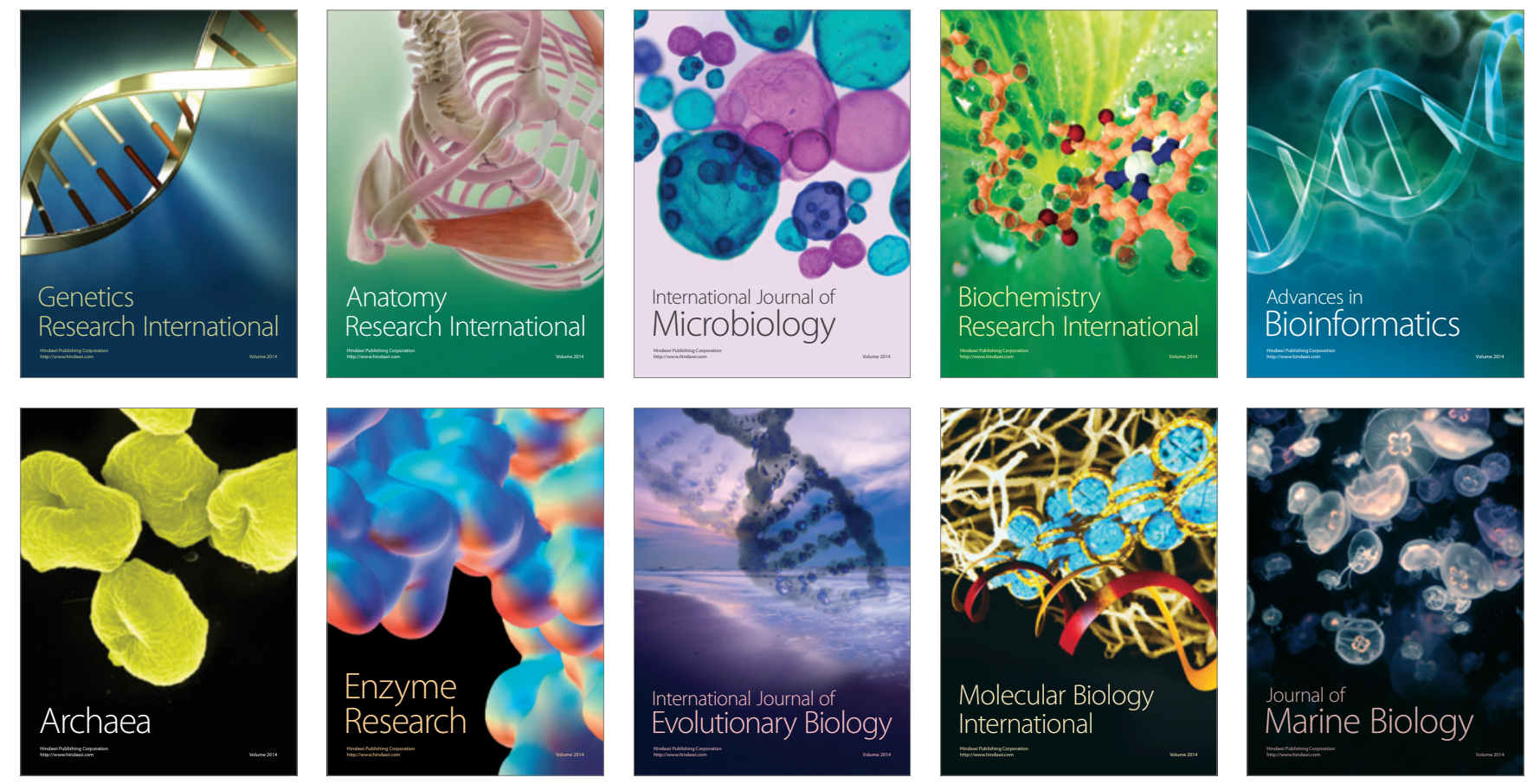